\title{
Orally administered $\beta$-glucan improves the hemolytic activity of the complement system in horses
}

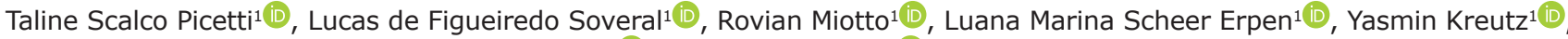 \\ João Antônio Guizzo ${ }^{(\mathbb{D}}$, Rafael Frandoloso ${ }^{1}$ (D) and Luiz Carlos Kreutz ${ }^{1}$ \\ 1. Laboratório de Microbiologia e Imunologia Avançada, Faculdade de Agronomia e Medicina Veterinária, Universidade de \\ Passo Fundo, 99052-900 Passo Fundo, RS, Brazil; 2. Programa de Pós-Graduação em Medicina Veterinária Preventiva, \\ Universidade Federal de Santa Maria, 97105-900 Santa Maria, RS, Brazil. \\ Corresponding author: Luiz Carlos Kreutz, e-mail: Ickreutz@upf.br \\ Co-authors: TSP: taline_scalco@yahoo.com.br, LFS: lucas-soveral@hotmail.com, RM: rovian.miotto@gmail.com, \\ LMSE: 168403@upf.br, YK: yasminkreutz@gmail.com, JAG: joaoguizzo@hotmail.com, RF: rfran@upf.br
}

Received: 02-12-2020, Accepted: 22-02-2021, Published online: 05-04-2021

doi: www.doi.org/10.14202/vetworld.2021.835-840 How to cite this article: Picetti TS, Soveral LF, Miotto R, Erpen LMS, Kreutz Y, Guizzo JA, Frandoloso R, Kreutz LC (2021) Orally administered $\beta$-glucan improves the hemolytic activity of the complement system in horses, Veterinary World, 14(4): 835-840.

\begin{abstract}
Background and Aim: Immune-modulating molecules mainly act on innate immune cells, which are central to early defense against invading pathogens and contribute to developing adaptive immunity. Yeast-extracted $\beta$-glucan, a model immune-modulating molecule, is widely used in several animal species; however, its effect on horse immune parameters has not been thoroughly investigated yet. This study aimed to evaluate the effects of orally administered $\beta$-glucan on selected innate immune parameters in horses.
\end{abstract}

Materials and Methods: Eighteen thoroughbred horses were assigned equally into three groups as follows: One control group (no $\beta$-glucan) and two $\beta$-glucan experimental groups (one received $125 \mathrm{mg}$ and the other $2 \mathrm{~g}$ of $\beta$-glucan per day for 28 days). Blood samples were collected before and at the end of the experiment for hematological analysis, whole blood phagocytosis, respiratory burst assays, and to assess the serum lysozyme and complement hemolytic activities.

Results: At the end of the experiment, significant decreases $(\mathrm{p}<0.05)$ in monocyte numbers were observed in the control

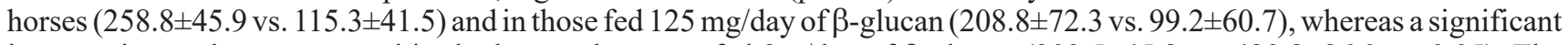
increase in numbers was noted in the horses that were fed $2 \mathrm{~g}$ /day of $\beta$-glucan $(303.5 \pm 45.8 \mathrm{vs} .429 .8 \pm 86.0 ; \mathrm{p}<0.05)$. The natural hemolytic activity of the complement was higher only in horses fed $2 \mathrm{~g}$ /day of $\beta$-glucan ( $\mathrm{p}=0.018)$ compared to the other groups. The hemolytic activity in the classical pathway was higher in those fed $125 \mathrm{mg} / \mathrm{day}(\mathrm{p}=0.0035)$ and $2 \mathrm{~g} / \mathrm{day}$ of $\beta$-glucan $(\mathrm{p}=0.0001)$.

Conclusion: $\beta$-glucan improves important innate immune parameters and might be fed to horses before stressful events.

Keywords: animals, glucans, monocytes, muramidase.

\section{Introduction}

Stressful situations such as parturition, weaning, training exercises, frequent transportation, and competition events have short-term negative effects on the immune response $[1,2]$ and might contribute to disease outbreaks in horses. The possibility of improving innate and acquired immune responses is central to good health and performance, and the use of immune modulators in horses is a subject of great interest to researchers, practitioners, and horse owners [3-6].

The use of immune-modulating molecules in horses has been poorly investigated and limited to few active components. Most widely used immune modulators contain molecules derived from pathogens, known as pathogen-associated molecular

Copyright: Picetti, et al. Open Access. This article is distributed under the terms of the Creative Commons Attribution 4.0 International License (http://creativecommons.org/licenses/by/4.0/), which permits unrestricted use, distribution, and reproduction in any medium, provided you give appropriate credit to the original author(s) and the source, provide a link to the Creative Commons license, and indicate if changes were made. The Creative Commons Public Domain Dedication waiver (http://creativecommons.org/ publicdomain/zero/1.0/) applies to the data made available in this article, unless otherwise stated. pattern (PAMP) molecules, which interact with pathogen recognition receptors (PRRs) found on the membrane surface or intracellular compartments of immune cells [7]. The interaction between PAMPs and PRRs triggers the activation of immune cells leading to activities such as improved phagocytosis and respiratory burst and the expression of key cytokines that coordinate subsequent immune events. In horses, the administration of Parapoxvirus ovis (PPVO) stimulates the mRNA expression levels of interferon $(I F N) \alpha, I F N \beta$, and $I F N \gamma$ in peripheral blood mononuclear cells [5,8-10] and improves the oxidative burst and phagocytosis of Rhodococcus equi by neutrophils [9]. In contrast, PPVO does not affect the development of cell-mediated immunity in weaned foals [11] or the incidence of pneumonia [5] in farms endemic for $R$. equi. The effects of Propionibacterium acnes (PA) on horse neutrophil respiratory burst and phagocytosis [5] have been investigated, but are not clear yet. Horses inoculated with Streptococcus zooepidemicus demonstrated a reduced incidence of endometritis and a downregulation in the expression levels of IL- $1 \beta$ on the endometrial cells after treatment with 
mycobacterial cell wall extract (MCWE) [4]. PPVO, $\mathrm{PA}$, and MCWE were parenterally administered in these studies, which limit their daily application over longer durations.

Ideally, immune-modulating molecules should be orally administered with food. The yeast-extracted $\beta$-glucan has been widely used as a food additive to improve the innate immune system of several animal species $[12,13]$. $\beta$-glucan has been shown to improve the overall resistance by increasing respiratory burst, phagocytosis, lysozyme, and complement activity in some animal species [14]. However, its effect on horses has been poorly investigated.

In this study, we aimed to investigate the effects of $\beta$-glucan, as a food additive, on blood leukocytes and selected innate immune parameters in English thoroughbred horses under regular training conditions.

\section{Materials and Methods}

\section{Ethical approval}

The study was carried out in accordance with the regulations of the National Council for the Control of Animal Experimentation and approved by the Committee of Ethics in Animal Experimentation (CEUA protocol number 016/2018) of the Universidade de Passo Fundo.

\section{Study period and location}

The experiment was carried out in March 2019 using horses that were housed and trained in a local horse farm at the municipality of Passo Fundo, Rio Grande do Sul $\left(28^{\circ} 15^{\prime} 40^{\prime \prime} \mathrm{S}, 52^{\circ} 24^{\prime} 30^{\prime \prime} \mathrm{W}\right.$ and $680 \mathrm{~m}$ altitude). Blood samples were analyzed at the Laboratório de Microbiologia e Imunologia Avançada, Universidade de Passo Fundo.

\section{Animals and experimental design}

Eighteen 2-year-old English thoroughbred horses ( 7 females and 11 males) were used in this study. All horses were considered healthy, according to physical and hematological examinations, and were treated for intestinal parasites followed by vaccinations according to the farm protocol. The animals were placed in individual stalls and on an exercise routine for 3 months when $\beta$-glucan (Biorigin, Brazil) was added to their diet. The diet was composed of a balanced commercial ration, Tifton- 85 hay, alfalfa, and water ad libitum. The horses were randomly and equally assigned to three groups: A control group (no $\beta$-glucan) and two experimental groups which received $125 \mathrm{mg} /$ day and $2 \mathrm{~g}$ /day of $\beta$-glucan, respectively, in the food for 28 days. All animals were kept in individual stalls and underwent an exercise regime once a day using the same protocol throughout the experimental period.

\section{Blood sampling and hematological analysis}

Peripheral blood samples were collected through jugular venipuncture before the start of feeding $\beta$-glucan (day 0) and at the end of the experiment (day 28). Blood samples for hematological analysis were aliquoted into EDTA tubes; samples used for whole blood phagocytosis and respiratory burst assays were aliquoted into heparin tubes and immediately placed on ice. A third blood aliquot was allowed to coagulate at $23^{\circ} \mathrm{C}$ to $27^{\circ} \mathrm{C}$ for $2 \mathrm{~h}$ to obtain serum for the immunological assays. After coagulation, the serum was carefully removed and frozen $\left(-20^{\circ} \mathrm{C}\right)$ until further analysis. The hematological parameters were immediately evaluated on whole blood samples, using the PocH-100iV equipment (Sysmex, Brazil), and on blood smears stained with Wright-Giemsa.

Whole blood phagocytic and respiratory burst assays

Bacterial phagocytosis and respiratory burst assays were performed using heparinized whole blood samples. The presence of anti-bacteria antibodies in horse serum could affect the outcome of the whole blood phagocytic assay in different animals; therefore, a dot blot assay was used to determine the presence of antibodies to selected bacteria (Escherichia coli, Staphylococcus aureus, Streptococcus equi, and Glaesserella parasuis) in the horses. Lack of serum reactivity on the dot blot assay was observed only with $E$. coli. Consequently, fluorescein isothiocyanate (FITC; Sigma-Aldrich, Brazil)-labeled E. coli (ATCC 25922) was used in the phagocytic and respiratory burst assays. In brief, E. coli was grown on LB media at $37^{\circ} \mathrm{C}$ under constant agitation $(200 \mathrm{rpm})$ until the optical density (OD) of the growing media reached 0.7 at $600 \mathrm{~nm}$. Then, the bacteria were inactivated by adding formalin to a final concentration of $0.5 \%$ and kept under agitation at $37^{\circ} \mathrm{C}$ for an additional $12 \mathrm{~h}$. The inactivated bacteria were harvested through centrifugation (20 min, $4500 \mathrm{rpm}$ ), washed 3 times with phosphate-buffered saline (PBS, pH 7,4), and counted using flow cytometry. FITC labeling was performed using $1 \mu \mathrm{g}$ of FITC per $1 \times 10^{9}$ bacteria in the dark (30 min at $22^{\circ} \mathrm{C}$ ), under constant agitation $(300 \mathrm{rpm})$. The bacteria were then washed again to remove excess FITC, diluted with PBS (containing 1\% of albumin), and stored in the dark at $4{ }^{\circ} \mathrm{C}$. The phagocytic assay was carried out as described previously [15], with slight modifications. In brief, $200 \mu \mathrm{L}$ of whole heparinized blood was mixed with $2 \times 10^{7}$ FITC-labeled E. coli $(25$ bacteria per leucocyte) and incubated at $37^{\circ} \mathrm{C}$ for 10 min. Then, the samples were placed on ice and mixed with red blood cell lysis buffer (Sigma-Aldrich) for 10 min. The samples were analyzed using BD FacsVerse flow cytometry (BD Life Sciences, Brazil) with forward scatter (FSC)-side scatter (SSC) linear amplification and biexponential fluorescence. Leukocytes were analyzed according to the size and complexity $(\mathrm{FSC} \times \mathrm{SSC})$; the phagocytic cells (polymorphonuclear and monocytes) were identified within the blood leukocyte population, and the fluorescence intensity and percentile of phagocytic cells (FL1 channel) were evaluated.

The respiratory burst assay was carried out similar to the whole blood phagocytic assay, but using 
non-labeled E. coli [15]. Non-labeled E. coli and $10 \mu \mathrm{L}$ of 2',7'-dichlorofluorescein diacetate (DCFH-DA, $500 \mu \mathrm{M}$, Sigma-Aldrich) were added simultaneously to whole blood aliquots $(200 \mu \mathrm{L})$, and the mixture was incubated for $10 \mathrm{~min}$ at $37^{\circ} \mathrm{C}$. The samples were ice refrigerated, and erythrocytes were lysed before evaluation using flow cytometry as described earlier.

\section{Serum Iysozyme activity determination}

Lysozyme activity in horse serum was determined through the turbidimetric assay using Micrococcus lysodeikticus, as described previously [16]. Briefly, $20 \mu \mathrm{L}$ of horse serum diluted in PBS (1:20) was mixed with $180 \mu \mathrm{L}$ of M. lysodeikticus (OD 0.5 at $450 \mathrm{~nm}$ ) in flat-bottomed plates. The samples were incubated at $23^{\circ} \mathrm{C}$, and $\mathrm{OD}$ was measured again at 1 and $4 \mathrm{~min}$ using an enzyme-linked immunosorbent assay plate reader (Synergy ${ }^{\mathrm{TM}}$ H1, BioTek, USA). The standard curve of lysozyme white chicken egg (SigmaAldrich, USA) was used as positive control, and lysozyme activity was calculated as follows: ([ $\Delta \mathrm{OD}$ $(4-1 \mathrm{~min}) / 3] / 0.001) \times 100$, where a reduction of 0.001 on the OD reading corresponded to $1 \mathrm{IU} / \mathrm{mL}$.

\section{Serum complement activity}

The hemolytic activity of the alternative and classical complement pathways in horse serum was evaluated. For the alternative pathway, $100 \mu \mathrm{L}$ of horse serum was diluted (factor 2) in HEPES-buffered saline (HBS, $150 \mathrm{mM} \mathrm{NaCl}, 135 \mathrm{nM} \mathrm{CaCl}, 1 \mathrm{mM}$ $\mathrm{MgCl}_{2}, 10 \mathrm{mM}$ HEPES, $\mathrm{pH}$ 7.2) containing $0.01 \%$ gelatin and $1 \mathrm{mM}$ ethylene-glycol-bis-tetraacetic acid (EGTA) [17] using "U"-shaped 96-well plates. The calcium-chelating EGTA was added to prevent the activation of the calcium-dependent classical complement pathway. Then, $50 \mu \mathrm{L}$ of chicken erythrocytes $(1 \%)$ were added and the plates incubated at $37^{\circ} \mathrm{C}$ for $1 \mathrm{~h}$ with gentle shaking every $10 \mathrm{~min}$. The plate was centrifuged $(230 \times g)$ for $5 \mathrm{~min}$ at $4^{\circ} \mathrm{C}$, and the supernatant was transferred to a flat-bottomed plate for OD reading at $412 \mathrm{~nm}$ (Synergy ${ }^{\mathrm{TM}}$ H1, BioTek, USA). Erythrocytes incubated with sterile water, or HBS only, presented $100 \%$ and $0 \%$ of hemolysis, respectively, which was used to calculate the hemolytic activity in each sample.

The hemolytic activity of the classical pathway was evaluated using a hemolytic solution (HS) containing chicken erythrocytes opsonized with rabbit anti-chicken antibodies. In brief, a rabbit was immunized through intravenous injection of $10 \%$ chicken erythrocyte solution ( $1 \mathrm{~mL} / \mathrm{kg}$ of body weight) on days $1,2,3,4,7$, and 11. Blood was collected through intracardiac puncture, under anesthesia, on day 14. The HS was prepared by mixing chicken erythrocytes $(2 \%)$ solution with an equal volume of HBS containing rabbit anti-chicken antibody (diluted to 1:1.500), incubated for $10 \mathrm{~min}$ at $37^{\circ} \mathrm{C}$, and then stored on ice until further use. For the classical complement hemolytic assay [17], $100 \mu \mathrm{L}$ of horse serum was diluted (factor 2 ) in HBS containing $0.01 \%$ gelatin (no EGTA) using
"U"-shaped 96-well plates, mixed with equal amounts of HS, and incubated at $37^{\circ} \mathrm{C}$ for $1 \mathrm{~h}$ with gentle mixing every $10 \mathrm{~min}$. The plate was centrifuged, and the supernatant was transferred to flat-bottomed 96-well plates and read at $412 \mathrm{~nm}$. Erythrocytes incubated with sterile water, or HBS only, presented $100 \%$ and $0 \%$ of hemolysis, respectively, and were used to calculate the hemolytic activity in allsamples. The OD values obtained by reading serum samples prior to the $\mathrm{CF}$ test were discounted from the final reading.

\section{Statistical analysis}

The data were evaluated using Shapiro-Wilk test and found to have a normal distribution. Blood parameters were analyzed using two-way analysis of variance (ANOVA) followed by Tukey's post-test; complement data were evaluated using two-way ANOVA followed by Dunnett's multiple comparison test. Data were plotted using the GraphPad Prism Software v7 (GraphPad Software, Inc., San Diego, CA, USA). The results are expressed as the mean \pm standard error of the mean, and $p \leq 0.05$ was considered statistically significant.

\section{Results}

\section{Effect of $\beta$-glucan on blood cells}

The hematological parameters were evaluated before (day 0) and 28 days after feeding the horses with $\beta$-glucan (125 mg/day or $2 \mathrm{~g} /$ day). The number of monocytes was significantly higher $(p<0.05)$ on day 28 in horses that were fed $2 \mathrm{~g}$ /day of $\beta$-glucan (Table-1); alternatively, on those horses, total serum protein levels were lower on day 28 compared with day 0 .

\section{Whole blood phagocytosis and respiratory burst assays}

Phagocytosis was measured as the percentile of phagocytic cells associated with FITC-labeled bacteria. The percentile of cells with attached bacteria was similar among groups on days 0 and 28 and was not altered by $\beta$-glucan supplementation (data not shown). Similarly, the percentile of fluorescent cells evaluated in the respiratory burst assay was similar on days 0 and 28 in all groups and was not affected by $\beta$-glucan feeding (data not shown).

\section{Serum lysozyme and both alternative and classical complement hemolytic activities}

Serum lysozyme activity was measured on days 0 and 28; no alterations following $\beta$-glucan treatment were detected (not shown). In contrast, the hemolytic activity of the alternative complement was significantly higher on day 28 in horses that received $2 \mathrm{~g}$ of $\beta$-glucan (Figure-1a). Furthermore, the hemolytic activity in the classical complement pathway was higher on day 28 in the two experimental groups of horses (Figure-1b).

\section{Discussion}

$\beta$-glucan is a linear polysaccharide extracted from the cell walls of yeast, algae, and fungi [12] 
Table 1: Hematological parameters of horses fed $\beta$-glucan. Blood samples were collected before (day 0 ) or after the feeding regimen (day 28 ). The data represent the mean $\pm \operatorname{SEM}(n=6)$.

\begin{tabular}{|c|c|c|c|c|c|c|}
\hline \multirow[t]{3}{*}{ Blood parameter } & \multirow{2}{*}{\multicolumn{2}{|c|}{ Control }} & \multicolumn{4}{|c|}{$\beta$-glucan } \\
\hline & & & \multicolumn{2}{|c|}{$125 \mathrm{mg} / \mathrm{day}$} & \multicolumn{2}{|c|}{$2 \mathrm{~g} / \mathrm{day}$} \\
\hline & Day 0 & Day 28 & Day 0 & Day 28 & Day 0 & Day 28 \\
\hline Erythrocytes $\left(10^{6} / \mu \mathrm{L}\right)$ & $10.9 \pm 0.45$ & $10.5 \pm 0.54$ & $11.2 \pm 0.36$ & $10.5 \pm 0.52$ & $10.9 \pm 0.49$ & $10.2 \pm 0.31$ \\
\hline Hemoglobin $(\mathrm{g} / \mathrm{l})$ & $14.1 \pm 0.36$ & $13.6 \pm 0.64$ & $13.6 \pm 0.27$ & $12.8 \pm 0.39$ & $13.4 \pm 0.41$ & $12.5 \pm 0.21$ \\
\hline Hematocrit $(\%)$ & $42.6 \pm 1.17$ & $41.3 \pm 1.95$ & $42.4 \pm 0.85$ & $39.8 \pm 1.24$ & $41.3 \pm 1.38$ & $38.9 \pm 0.68$ \\
\hline VHS (mm/h) & $39.2 \pm 1.16$ & $39.5 \pm 1.16$ & $37.9 \pm 0.85$ & $37.9 \pm 0.81$ & $33.9 \pm 4.03$ & $39.2 \pm 0.82$ \\
\hline $\mathrm{HCM}(\mathrm{pg})$ & $13.0 \pm 0.50$ & $13 \pm 0.55$ & $12.4 \pm 0.36$ & $12.2 \pm 0.30$ & $12.4 \pm 0.28$ & $12.4 \pm 0.28$ \\
\hline CHCM $(g / d l)$ & $33.1 \pm 0.35$ & $32.9 \pm 0.40$ & $32.1 \pm 0.13$ & $32.1 \pm 0.14$ & $32.3 \pm 0.24$ & $32.3 \pm 0.31$ \\
\hline Total leukocytes $(\mu \mathrm{L})$ & $10.1 \pm 1.10$ & $8.4 \pm 487$ & $9.167 \pm 300$ & $8.000 \pm 619$ & $8.1 \pm 319$ & $7.1 \pm 305$ \\
\hline Bastonated neutrophils $(\mu \mathrm{L})$ & $48.3 \pm 21.62$ & $13.2 \pm 12.01$ & $28.3 \pm 25.86$ & $0 \pm 0$ & $13.6 \pm 12.47$ & $11.7 \pm 10.65$ \\
\hline Segmented neutrophils $(\mu \mathrm{L})$ & $6296 \pm 1227.0$ & $3876.6 \pm 405.3$ & $4593.7 \pm 264.4$ & $3325.2 \pm 326.3$ & $3994.2 \pm 317.5$ & $2921.8 \pm 130.8$ \\
\hline Eosinophils $(\mu \mathrm{L})$ & $203.8 \pm 95.36$ & $152.2 \pm 40.32$ & $133.3 \pm 55.55$ & $149 \pm 53.11$ & $86.7 \pm 40.35$ & $104.8 \pm 12.58$ \\
\hline Basophils $(\mu \mathrm{L})$ & $35.3 \pm 0$ & $0 \pm 0$ & $0 \pm 20.94$ & $0 \pm 0$ & $0 \pm 0$ & $0 \pm 0$ \\
\hline Lymphocytes $(\mu \mathrm{L})$ & $6107.6 \pm 354.8$ & $4186.8 \pm 526.5$ & $4202.5 \pm 2400$ & $4426.6 \pm 253.8$ & $3718.7 \pm 336.8$ & $3665 \pm 304.12$ \\
\hline Monocytes $(\mu \mathrm{L})$ & $258.8 \pm 45.9$ & $115.3 \pm 41.5^{\mathrm{A}}$ & $208.8 \pm 72.3$ & $99.2 \pm 60.7^{A}$ & $303.5 \pm 45.8$ & $429.8 \pm 86.0^{B}$ \\
\hline Platelets count $(\mu \mathrm{L})$ & $182.0 \pm 26.4$ & $173.7 \pm 11.3$ & $255.3 \pm 14.7$ & $219.333 \pm 14.0$ & $189.000 \pm 8.9$ & $211.33 \pm 9.9$ \\
\hline Total protein $(\mathrm{g} / \mathrm{dl})$ & $8.1 \pm 0.09^{a}$ & $7.6 \pm 0.13^{b}$ & $7.9 \pm 0.09$ & $7.6 \pm 0.09$ & $8 \pm 0.08^{a}$ & $7.5 \pm 0.08^{\mathrm{b}}$ \\
\hline
\end{tabular}

Significant differences $(p<0.05)$ within the same group are represented by small letters and differences between groups are represented by capital letters. HCM=Mean Corpuscular Hemoglobin, VHS=, Erythrocyte Sedimentation Rate $\mathrm{CHCM}=$ Mean Corpuscular Hemoglobin Concentration

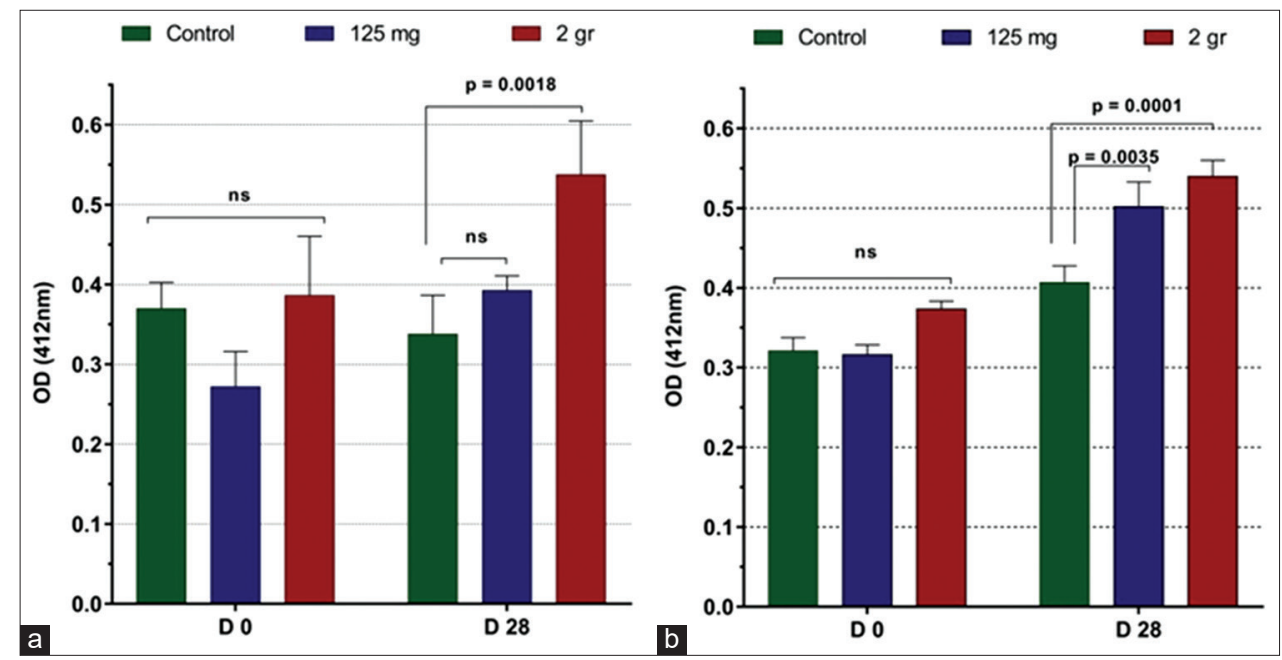

Figure-1: Horse serum (a) alternative and (b) classical complement pathway activation on chicken erythrocytes. Data are expressed as the optical density $\left(\mathrm{OD}_{412 \mathrm{~nm}}\right)$ mean $\pm \operatorname{SEM}(n=6)$ obtained from the supernatant of lysed erythrocytes. Supernatant from $100 \%$ hemolysis had an $\mathrm{OD}_{412}$ of 0.750 . Significant differences among treatment are indicated ( $p$-value).

that can function as PAMPs and be administered as food additives to animals to improve both innate and acquired immunity [14]. The interaction between $\beta$-glucan and its cognate receptor on immune cells (e.g., macrophage and dendritic cells) triggers the expression of cytokines, which orchestrates innate and acquired immune responses [13]. The immune-modulating effects of $\beta$-glucan have been demonstrated in several animal species [13], including fish [18]; however, their effect in horses has not been demonstrated so far. The advantage of $\beta$-glucan over other PAMPs evaluated in horses is that it can be administered orally, rather than through parenteral injections. However, the effects of $\beta$-glucans are better noticed after a prolonged period of feeding; moreover, the in vivo effects are rather discrete compared with the in vitro effects [19]. Nonetheless, this study provides data favoring the use of $\beta$-glucan as an innate immune modulator in horses.

$\beta$-glucan is an insoluble non-digestive carbohydrate [14], which interacts with pinocytic microfold $M$ cells located in the small intestine[12] and immune cells, such as macrophages in Peyer's patches. Macrophage-processed $\beta$-glucan can be transported to the lymph nodes, spleen, and bone marrow [20], enhancing the expression of several immune-related genes, including the complement pathway-related genes [21]. The feeding of algae-derived $\beta$-glucan to weaned $E$. coli challenged piglets resulted in a reduction in the transcellular permeability of the gut [22], delay in the onset of diarrhea, and a reduction in the number of blood neutrophils. In the current study, $\beta$-glucan had no significant effect on the number of blood leukocytes, except for monocytes, in the horses. 
The monocyte count on day 28 was lower than that on day 0 in horses that were fed $125 \mathrm{mg} /$ day of $\beta$-glucan. However, a reduction in monocyte counts was observed in the control group as well; hence, it cannot be attributed to $\beta$-glucan. In contrast, horses fed with $2 \mathrm{~g}$ of $\beta$-glucan had a significantly higher number of blood monocytes at the end of the feeding regimen. Blood monocytes are central to innate immunity; they migrate from blood to tissues, monitor the invading pathogens, and secrete cytokines that direct the appropriate immune responses [23].

In addition, monocytes secrete anti-microbial peptides, lysozymes, and complement components that further improve the innate defense [24]. In the present study, serum lysozyme activity was highly variable within and among the groups, but not significantly different or affected by $\beta$-glucan treatment. However, the hemolytic activity of the alternative and classical complement system was higher in horses that received $\beta$-glucan. Complement components are produced mostly by hepatocytes and mononuclear cells. In mammals, the complement system is central to innate and acquired immunity. On activation, key components of the complement system are activated, and a cascade of enzymatic reactions is initiated that results in the formation of the membrane attack complex on the surface of the target pathogen [25]. In addition, complement activation leads to the production of several soluble intermediary components with important roles in immune cell chemotaxis, microbial opsonization, destruction, and phagocytosis [26], mostly by neutrophils that are attracted to the site of infection. The complement system in horses and its role in protecting against invading pathogens have been poorly investigated. Early studies indicated that horses had a potent alternative complement pathway capable of readily lysing rabbit erythrocytes [27] but not sheep erythrocytes [28]. Thus, the efficacy of the complement system in horses might depend on the pathway activated and the target antigen. In the current study, we investigated the activation of both the alternative and classical complement pathways and found that feeding horses with $\beta$-glucan had a significant effect on the hemolytic activity against chicken erythrocytes (target cells) during both alternative and classical pathway activations. Complement activation through the alternative pathway begins with the spontaneous deposition of a key complement component, the $\mathrm{C} 3 \mathrm{~b}$ molecule, on the target cell surface, whereas classical pathway activation occurs after the binding of the $\mathrm{C} 1 \mathrm{q}$ molecule to antibodies attached to the target cell [25]. Thus, the complement system plays a major role in innate and acquired immunity in most animal species. Data on the effect of $\beta$-glucan on the hemolytic activity of the complement system in mammals are scarce, probably due to challenges in standardizing the hemolytic assay to each species. Alternatively, non-hemolytic assays that measure complement activation by detecting the byproduct depend on specific reagents and anti-complement component antibodies that are not readily available.

\section{Conclusion}

The use of immune modulators in horses is in its incipient stage and needs to be explored further. Some immune modulation therapies and compounds have proven beneficial, but many others lack scientific verification. In this study, we demonstrated that feeding horses with $\beta$-glucan improve immune-related cells and booster complement activation, a major component of humoral immunity in mammals. These findings warrant further investigations, particularly concerning the dosage and treatment regimen. Additional tools are required to investigate the effects of $\beta$-glucan on the expression of the immune-related genes in vivo and in vitro to better understand its potential use as an immune modulator in horses.

\section{Authors' Contributions}

TSP and LCK: Conception and design of the study. TSP, LFS, JAG, RM, LMSE, and YK: Acquisition of the data. LCK, TSP, JAG, and RF: Analysis and interpretation of the data. TCP, RF, and LCK: Analyzed the data and drafted the manuscript. LCK: Critical revision of the manuscript. All authors read and approved the final manuscript.

\section{Acknowledgments}

Taline Scalco Picetti and Lucas de Figueiredo Soveral were Master Students supported by the Fundação Universidade de Passo Fundo (FUPF) and the Coordenação de Aperfeiçoamento de Pessoal de Nível Superior - Brazil (CAPES) - Finance Code 001. Rovian Miotto, Luana Marina Scheer Erpen and Yasmin Kreutz are undergraduate students supported by FUPF and the National Council for Research and Scientific Development (CNPq) Fellowships. João Antônio Guizzo is a doctorate student supported by a fellowship from CAPES - Finance Code 001. Luiz Carlos Kreutz holds a fellowship from CNPq (PQ $307900 / 2016-9)$. Biorigin provided $\beta$-glucan for the study.

\section{Competing Interests}

The authors declare that they have no competing interests.

\section{Publisher's Note}

Veterinary World remains neutral with regard to jurisdictional claims in published institutional affiliation.

\section{References}

1. Frellstedt, L., Gosset, P., Kervoaze, G., Hans, A., Desmet, C., Pirottin, D., Bureau, F., Lekeux, P. and Art, T. (2015) The innate immune response of equine bronchial epithelial cells is altered by training. Vet. Res., 46(3): 1-12.

2. Frellstedt, L., Waldschmidt, I., Gosset, P., Desmet, C., Pirottin, D. and Art, T. (2014) Training modifies innate immune responses in blood monocytes and in pulmonary 
alveolar macrophages. Am. J. Respir. Cell Mol. Biol., 51(1): 135-142.

3. Horohov, D.W., Breathnach, C.C., Sturgill, T.L., Rashid, C., Stiltner, J.L., Strong, D., Nieman, N. and Holland, R.E. (2008) In vitro and in vivo modulation of the equine immune response by Parapoxvirus ovis. Equine Vet. J., 40(5): 468-472.

4. Woodward, E.M., Christoffersen, M., Horohov, D., Squires, E.L. and Troedsson, M.H.T. (2015) The effect of treatment with immune modulators on endometrial cytokine expression in mares susceptible to persistent breeding-induced endometritis. Equine Vet. J., 47(2): 235-239.

5. Paillot, R. (2013) A systematic review of the immune-modulators Parapoxvirus ovis and Propionibacterium acnes for the prevention of respiratory disease and other infections in the horse. Vet. Immunol. Immunopathol., 153(1-2): 1-9.

6. Davis, E. (2013) The Use of Vaccines and Immunostimulants in the Horse. In: NAVC Conference 2013 Large Animals. p1-12. Available from: https://www.vetfolio.com/learn/ article/the-use-of-vaccines-and-immunostimulants-in-thehorse9/12. Retrieved on 31-10-2020.

7. Bergmann-Leitner, E. and Leitner, W. (2014) Adjuvants in the driver's seat: How magnitude, type, fine specificity and longevity of immune responses are driven by distinct classes of immune potentiators. Vaccines, 2(2): 252-296.

8. Friebe, A., Siegling, A., Friederichs, S., Volk, H., Weber, O. and Ag, B.H. (2004) Immunomodulatory effects of inactivated Parapoxvirus ovis (Orf virus) on human peripheral immune cells: Induction of cytokine secretion in monocytes and Th1-like cells. J. Virol., 78(17): 9400-9411.

9. Ryan, C., Giguére, S., Fultz, L., Long, M.T. and Crawford, P.C. (2010) Effects of two commercially available immunostimulants on leukocyte function of foals following ex vivo exposure to Rhodococcus equi. Vet. Immunol. Immunopathol., 138(3): 198-205.

10. Hue, E.S., Id, E.A.R., Fortier, C.I., Fortier, G.D., Paillot, R., Raue, R. and Pronost, L. (1930) Equine PBMC cytokines profile after in vitro $\alpha$-and $\gamma$-EHV infection: Efficacy of a Parapoxvirus ovis based-immunomodulator treatment. Vaccines, 5(28): 1-17.

11. Adams, A.A. and Horohov, D.W. (2013) The effect of an immunomodulator (Parapoxvirus ovis) on cell-mediated immunity (CMI) in abruptly weaned foals. Vet. Immunol. Immunopathol., 153(1-2): 118-122.

12. Stier, H., Ebbeskotte, V. and Gruenwald, J. (2014) Immunemodulatory effects of dietary yeast beta-1, 3/1, 6-D-glucan. Nutr. J., 13(1): 1-9.

13. Soltanian, S., Stuyven, E., Cox, E., Sorgeloos, P. and Bossier, P. (2009) Beta-glucans as immunostimulant in vertebrates and invertebrates. Crit. Rev. Microbiol., 35(2): 109-138.

14. Camilli, G., Tabouret, G. and Quintin, J. (2018) The complexity of fungal $\beta$-glucan in health and disease: Effects on the mononuclear phagocyte system. Front. Immunol., 9:673.

15. Cywinska, A., Szarska, E., Degorski, A., Guzera, M., Gorecka, R., Strzelec, K., Kowalik, S., Schollenberger, A. and Winnicka, A. (2013) Blood phagocyte activity after race training sessions in Thoroughbred and Arabian horses.
Res. Vet. Sci., 95(2): 459-464.

16. Sutili, F.J., Kreutz, L.C., Flores, F.C., da Silva, C.B., Kirsten, K.S., Ana, P., Voloski, S., Frandoloso, R., Pinheiro, C.G., Heinzmann, B.M. and Baldisserotto, B. (2019) Effect of dietary supplementation with citral-loaded nanostructured systems on innate immune responses and gut microbiota of silver catfish (Rhamdia quelen). J. Funct. Foods, 60: 103454.

17. Zelek, W.M., Harris, C.L. and Morgan, B.P. (2018) Extracting the barbs from complement assays: Identification and optimisation of a safe substitute for traditional buffers. Immunobiology, 223(12): 744-749.

18. Dalmo, R.A. and Bøgwald, J. (2008) Beta-glucans as conductors of immune symphonies. Fish Shellfish Immunol., 25(4): 384-396.

19. Leentjens, J., Quintin, J., Gerretsen, J., Kox, M., Pickkers, P. and Netea, M.G. (2014) The effects of orally administered beta-glucan on innate immune responses in humans, a randomized open-label intervention pilot-study. PLoS One, 9(9): 1-6.

20. Hong, F., Yan, J., Baran, J.T., Allendorf, D.J., Hansen, R.D., Ostroff, G.R., Xing, P.X., Cheung, N.V. and Ross, G.D. (2004) Mechanism by which orally administered $\beta$-1, 3-glucans enhance the tumoricidal activity of antitumor monoclonal antibodies in murine tumor models. J. Immunol., 173(2): 797-806

21. Pionnier, N., Falco, A., Miest, J., Frost, P., Irnazarow, I., Shrive, A. and Hoole, D. (2013) Dietary $\beta$-glucan stimulate complement and C-reactive protein acute phase responses in common carp (Cyprinus carpio) during an Aeromonas salmonicida infection. Fish Shellfish Immunol., 34(3): 819-831.

22. Stuyven, E., Cox, E., Vancaeneghem, S., Arnouts, S., Deprez, P. and Goddeeris, B.M. (2009) Effect of B-glucans on an ETEC infection in piglets. Vet. Immunol. Immunopathol., 128(1-3): 60-66.

23. Kapellos, T.S., Bonaguro, L., Gemünd, I., Reusch, N., Saglam, A., Hinkley, E.R. and Schultze, J.L. (2019) Human monocyte subsets and phenotypes in major chronic inflammatory diseases. Front. Immunol., 10: 2035.

24. Kantari, C., Pederzoli-Ribeil, M. and Witko-Sarsat, V. (2008) The role of neutrophils and monocytes in innate immunity. Trend Innate Immun., 15: 118-146.

25. Heesterbeek, D.A.C., Angelier, M.L., Harrison, R.A. and Rooijakkers, S.H.M. (2018) Complement and bacterial infections: From molecular mechanisms to therapeutic applications. J. Innate Immun., 10(5-6): 455-464.

26. Hawlisch, H. and Köhl, J. (2006) Complement and toll-like receptors: Key regulators of adaptive immune responses. Mol. Immunol., 43(1-2): 13-21.

27. Leid, R.W., Coley, S.C., Blanchard, D.P. and Perryman, L.E. (1985) Equine alternative pathway activation by unsensitized rabbit red blood cells. Vet. Immunol. Immunopathol., 9(1): 71-85.

28. Yarnall, D. and Boyle, M.D.P. (1986) Restriction in the lytic efficiency of complement on different erythrocyte targets: A re-examination of the activities of horse $\mathrm{C} 8$ and C9. Mol. Immunol., 23(8): 823-829. 